\title{
Confiar para conviver
}

\section{SINNER, Rudolf von. Confiança e convivência: reflexões éticas e ecumênicas. São Leopoldo: Sinodal, 2007.}

\author{
Antonio Carlos Ribeiro
}

Essas expressões são enfatizadas por Gottfried Brakemeier, ex-presidente da Igreja Evangélica de Confissão Luterana no Brasil e da Federação Luterana Mundial, ao destacar a necessidade da convivência dos povos, das religiões e das igrejas, na apresentação desta obra composta de coletânea de artigos de Rudolf von Sinner, teólogo reformado e professor de teologia ecumênica na Escola Superior de Teologia.

O autor começa lembrando o Grande Inquisidor, do romance clássico Os irmãos Karamázovi, de Fiódor Dostoiévski. O cardeal espanhol defende o poder e a autoridade da igreja frente à qual, segundo ele, o povo reage melhor ao submeter-se do que quando confrontado com a liberdade. Jesus, ao curar pessoas de suas dores físicas e espirituais, é feito prisioneiro. A revelação que brota, ao ser interrogado pelo inquisidor, é que ele apostou na qualidade humana, que produz confiança e possibilita a convivência, e fez dela a base de sua pregação do Reino de Deus. Apesar da forte tentação, o inquisidor não se converteu. E mandou o prisioneiro embora na noite escura.

Essa confiança é uma necessidade nas sociedades latino-americanas, das situações do dia-a-dia à confiabilidade das instituições. $\mathrm{O}$ abalo vem do fato da igualdade ainda ser uma necessidade sentida, frente ao poder das classes ricas de proteger seus interesses, fragilizando a confiança. As sociedades que avançam são as que pautam a convivência na confiança, nas quais o cidadão tem segurança de que os direitos serão protegidos. Com senso pastoral, o autor analisa os aspectos destas relações, lembrando os imperativos éticos dos evangelhos, relacionando a ética mínima e a exigência maior e enfatizando que

\footnotetext{
${ }^{1}$ Teólogo luterano, ex-secretário do Conselho de Igrejas Cristãs do Estado do Rio de Janeiro (CONIC-Rio) e Doutorando em Teologia (PUC-Rio), Brasil. E-mail: antoniocarlosrib@gmail.com
}

Horizonte, Belo Horizonte, v. 7, n. 15, p.185-190, dez. 2009 
confiança é dádiva, exige convicção e mostra sinais quando o leitor e o texto se interpretam mutuamente. Leitura da bíblia e das pessoas supõe a confiança que propicia a convivência, enquanto a coerção, exercida em nome da fé, da pureza e da comunhão, fere a confiança. Assim se aprende que o Espírito fala em meio às diferenças doutrinais.

O primeiro paradigma é abordado a partir da obra A Trindade, a sociedade e a libertação, de Leonardo Boff, que aborda o tema tendo como pano de fundo o conjunto da realidade brasileira e a estrutura eclesial. A primeira, marcada pela distensão lenta, gradual e segura do regime militar, e a segunda, na euforia revisionista do Vaticano II. Esse período testemunha a coincidência da diminuição da repressão política e os conflitos teológicopastorais, as perspectivas popular e ecumênica, unindo católicos e evangélicos na mística e na resistência política. O teólogo von Sinner mapeou fatos, momentos e instituições, da vida civil e religiosa - os que legitimaram as instituições e os que exerceram papel fundamental na luta pela superação - em meio a níveis alarmantes de miséria, que fizeram a América Latina permanecer à margem da história ocidental, segundo Hobsbawn.

Boff elabora conceitos teológicos da Trindade numa doutrina social e cósmica, vendo-a como um programa social, sem disputas acirradas e apresentando-a em contraposição à perspectiva monárquica da religião e da política na AL. Esta é descrita como colonial e feudal (religião de um só Pai), na qual o militante passa a ver Jesus como irmão, chefe e mestre (religião só do Filho) e, com subjetividade, criatividade e interioridade em extremo pode-se chegar ao fanatismo e anarquismo (religião só do Espírito). Nesta situação, a Trindade se torna modelo a criticar os modelos eclesiais e protótipo da comunidade humana sonhada pelos que querem melhorar a sociedade. A perichóresis ajuda a entender o amor recíproco entre as pessoas da Trindade e a diferença de sua individualidade, possibilitando igual movimento aos seres humanos. A relação Trindade, igreja e sociedade civil, mostra como a sociedade civil e a religiosa podem ser influenciadas. A ênfase recai sobre a maior igualdade possível entre as pessoas e a geração de processos mais abrangentes de participação, acentuando o respeito à alteridade, a participação, a confiança e a coerência.

A Teologia Pública enfatiza esse caráter da fé cristã. Segundo David Tracy, aos públicos teológicos clássicos (sociedade, academia e igreja) juntaram-se outros como a economia e a mídia, razão pela qual ela escolheu o espaço público para exercer sua tarefa. 
A Teologia da Cidadania neste continente atendeu pelo nome de Teologia da Libertação (TL), teve como precursores Richard Shaull e Rubem Alves, e ganhou fundamentação teórica e densidade - eclesial e política - com teólogos como Gustavo Gutiérrez, Leonardo Boff, Clodovis Boff e Juan Luís Segundo, colocando a teologia em movimento, criando a base para uma significativa consciência do caráter contextual geral da teologia e em primeiro plano a teologia proveniente da margem e movimentos similares - teologias do Terceiro Mundo - na Associação Ecumênica de Teólogos e Teólogas do Terceiro Mundo (ASETT), que têm contribuído para a descolonização teológica. Desse modo, congregou as teologias negra e feminista, pluralizou o conceito de libertação e garantiu um estatuto ontológico, situado histórica, pessoal e bibliograficamente. Partiu da opção preferencial pelos pobres, assumida pelas assembléias do episcopado latino-americano em Medellín e Puebla, e, segundo Comblin, tornou-se o melhor da história da Igreja na América Latina nos últimos 30 anos. Inseriu-se no meio dos pobres, participando diretamente em seu diaa-dia, em meio a grandes lutas para poder viver humanamente, apesar de tudo.

A TL criou a base para a Teologia Pública na década de 80 e parece ter sobrevivido à queda do muro de Berlim (1989), já que ainda é criticada por autoridades das Igrejas, tem teólogos-as de expressão em pastorais, assessorias, docência e publicações, e mantém ininterruptos os Encontros intereclesiais de Comunidades Eclesiais de Base (CEBs) e criou relações com as Teologias do Pluralismo Religioso (TPR) e GLBT. Ao mesmo tempo, se mostra deficiente e tem pouca intervenção ao enfrentar indigência, criminalidade, corrupção e política clientelista. Precisa atualizar o discurso, com propostas para o direito e o espaço público, com vistas a uma cidadania ativa e emancipada numa sociedade que, mesmo com os avanços, ainda convive com estupendos retrocessos. Diante da impossibilidade de conter o êxodo rural, disse Comblin, deve ensinar a ser cidadão. Esse esforço pode ajudar a abordar questões contemporâneas, confirmar seu lugar na universidade e estabelecer relações com as comunidades científica, religiosa e política, sem perder de vista os pobres, que são as não-pessoas, os 'in-significantes', os que não contam nem para o resto da sociedade nem, 'freqüentemente demais', para as igrejas cristãs, como disse Gutiérrez.

A proposta do luterano francês Oscar Cullmann, de católicos levantarem uma oferta para protestantes pobres e vice-versa, assemelha-se ao acordo entre Paulo e Pedro que 
possibilitou a missão aos gentios no $1^{\circ}$ século, além do atendimento aos pobres. A intenção é que isso pusesse fim à desconfiança mútua. A Conferência Nacional dos Bispos do Brasil (CNBB) realizou junto com o Conselho Nacional de Igrejas Cristãs do Brasil (CONIC) uma Campanha da Fraternidade conjunta, possibilitando o sonho ecumênico, criando um ambiente de confiança e convivência, e atenuando a concorrência, os anátemas e o ecumenismo balizado institucionalmente. Os esforços para articulação de uma voz única das igrejas sempre enfrentaram dificuldades, apesar dos grandes esforços. Até mesmo nas decisões das assembléias do Conselho Mundial de Igrejas (CMI) pelas iniciativas pela paz, na campanha de solidariedade com as mulheres e na proposta da Nova Década de Superação da Violência.

Com uma Hermenêutica ecumênica, von Sinner busca as razões do malogro das propostas, a partir dos documentos trazidos pela Comissão Fé e Ordem e pelas assembléias do CMI, tratando de busca de consensos, metodologia e hermenêutica ecumênicas, intercontextualidade e linguagem comum. Um dos resultados desse esforço foi o documento Um tesouro em vasos de argila, propondo uma ética a partir da compreensão do evangelho e do contexto atual. Hermenêutico é o espaço em que as igrejas se encontram e dialogam sobre a interpretação e recepção dos seus textos, símbolos e práticas, elaborando hermenêuticas da coerência, da confiança e da suspeita. Para demonstrar isso, ele escolheu dois teólogos católicos: o brasileiro Leonardo Boff e o espanhol Raimon Panikkar. O primeiro por trabalhar a imagem trinitário-comunitária de Deus, apresentando um modelo relacional das pessoas da Trindade que denuncia a estrutura autoritária da sociedade brasileira e o poder religioso hierarquizado da igreja católica, propondo uma ação no mundo. O segundo, desenvolveu uma teologia a partir do encontro da Índia com o ocidente, denunciou que o ecumenismo não pode ser apenas intracristão, mas deve estabelecer diálogo com outras religiões, explicando que nenhuma religião pode oferecer sozinha soluções de validade universal para os problemas humanos. E, por enfatizar a confiança cósmica e a abertura fundamental como essenciais ao diálogo, propondo o instrumento da intuição cosmoteândrica.

O diálogo inter-religioso surge como necessidade para as religiões, após a tentativa de dimensionar a experiência do sagrado, ao se encontrarem no diálogo com as outras. Os teólogos europeus da primeira metade do século passado, católicos e evangélicos, viveram 
a impactante experiência de duas guerras mundiais, inclusive com um regime de caráter quase-religioso. Os modelos de relacionamento inter-religioso gestados nesse período, dividem-se em exclusivismo, inclusivismo e pluralismo, com nomes de expressão, dos mundos católico e evangélico, para cada postura. O exclusivismo foi atenuado no Concílio Vaticano II com o surgimento do inclusivismo, a partir da influência da antropologia teológica de Karl Rahner. A experiência de diálogo entre o cristianismo e o hinduísmo mostra-se na teologia de Panikkar, especialmente no conceito de intuição cosmoteândrica a sustentar o pluralismo, a partir do Vaticano II. Essas noções foram acolhidas em espaços protestantes (Smith e Hick). A partir desse conjunto, von Sinner distingue o diálogo em diferentes níveis e a partir de distintas perspectivas, destacando a fala na primeira pessoa, a partir da confiança em Deus, pela qual pode sentir também confiança nas outras pessoas, o outro com o qual se desenvolve o diálogo.

O capítulo final descreve a disposição da perspectiva ecumênica do CMI. Essa comunhão de igrejas que aceitam Jesus Cristo como Deus e Salvador segundo as Escrituras e que possibilita o encontro de pessoas de fé e culturas diferentes, embora se recuse ser chamada de igreja e nem de vaticano dos protestantes e ortodoxos. Os vínculos estão baseados nas relações entre elas. As igrejas-membros mantém sua própria eclesiologia, mesmo as que não reconhecem a alheia, como as igrejas ortodoxas. Por isso mesmo podem congregar igrejas de tipo sacramental, reformado, conversionista e carismático, com divergências, algumas profundas, mas sem imposições. Isso possibilita crer que as igrejas são perpassadas pelas diferenças (corpus permixtum) e que a catolicidade da Igreja de Cristo transcende as fronteiras. Essa estrutura possibilita avanços como a compreensão de que Deus é semper maior (Loyola) que estruturas e conceitos humanos, que o diálogo faz avançar a perspectiva teológica dentro da própria igreja, e que é possível conviver com uma diversidade de eclesiologias.

O conjunto dos textos de Rudolf von Sinner mostram pesquisa e dedicado trabalho teológico, num tema não muito freqüente entre teólogos protestantes, especialmente em língua vernácula. Sua contribuição entabula uma conversa pela qual os evangélicos talvez tenham se interessado pouco, por causa das diferenças e por terem se acostumado a um ecumenismo de representação institucional, publicação de documentos e pouco enraizamento no conhecimento mútuo e no enfrentamento das diferenças. E, da mesma 
forma, debruça-se sobre o modelo do diálogo universal de culturas do CMI. Nos dois casos, o autor esforça-se por apresentar conceitos e propostas de práticas religiosas que não são familiares ao universo religioso popular, por isso a importância para o contexto brasileiro. Trata-se de um teólogo suíço que, baseando-se em teólogos católicos, que partem de situações e usam instrumentais distintos, descobrem conceitos diferentes, mas compatíveis. E, por último, o apelo à confiança como base para a convivência, num texto culto, não doutrinal e bem informado, torna-se uma motivação para o debate do ecumenismo e do diálogo inter-religioso nessas plagas. 